\title{
New species and records of the genus Thaumaglossa Redtenbacher, 1867 (Coleoptera: Dermestidae: Megatominae) from South East Asia
}

\author{
J. Háva \\ И. Гава
}

Ава новых вида рода Thaumaglossa Redtenbacher, 1867 (Coleoptera: Dermestidae: Megatominae) из Юго-Восточной Азии

Forestry and Game Management Research Institute, Strnady 136, Praha 5 - Zbraslav CZ-252 02 Czech Republic. E-mail: jh.dermestidae@volny.cz.

Научно-исследовательский институт охотничьего хозяйства, Стрнады 136, Praha 5 - Збраслав CZ-252 02 Чехия.

Key words: taxonomy, new species, new records, Coleoptera, Dermestidae, Thaumaglossa, Oriental Region.

Ключевые слова: таксономия, новые виды, новые находки, Coleoptera, Dermestidae, Thaumaglossa, Opиентальная область.

Abstract. Two dermestid beetle species, Th. mentawaiana sp.n. from Siberut Island of Indonesia and Th. sausai sp.n. from Laos and Thailand, both belonging to Thaumaglossa hilleri species group, but differ by the structure of their antennae and male genitalia, are described, illustrated and compared with related species. Two species are also recorded in the region for the first time, namely Th. pacholatkoi Háva, 2015 for Java Island of Indonesia, and Th. panda Herrmann et Háva, 2015 for the Hubei province of China.

Pезюме. В статье описываются два новых вида рода Thaumaglossa, принадлежащих к видовой группе Th. hilleri, Th. mentawaiana sp.n. из Индонезии и Th. sausai sp.n. из Лаоса и Таиланда. Новые виды отличаются от близких видов строением усиков и гениталиями самцов. Новые находки Th. pacholatkoi Háva, 2015 приводятся из Явы (Индонезия) и Th. panda Herrmann et Háva, 2015 из Хубэя (Китай).

\section{Introduction}

The dermestid genus Thaumaglossa Redtenbacher, 1867 belongs to the subfamily Megatominae, tribe Megatomini, subtribe Cryptorhopalina and recently contains 62 species and subspecies worldwide [Háva, 2015a, 2020]. The genus Thaumaglossa was recently studied and new species were recently published for example by Háva [2008, 2010, 2012, 2015b-d, 2017], Háva et al. [2006], Háva, Jákl [2018], Herrmann, Háva [2013, 2015] and Kadej, Háva [2013, 2015]. In the present article, two new species are described.

\section{Material and Methods}

The species are listed in the alphabetical order, the nomenclature and zoogeography follow the catalogue of Háva [2015a].

The following abbreviations of measurements were used:

Total length (TL) - linear distance from anterior margin of pronotum to apex of elytra. tance.

Elytral width $(\mathrm{EW})$ - maximum linear transverse dis-
Type material deposited in the following collection: JHAC - Private Entomological Laboratory \& Collection, Jiří Háva, Únětice u Prahy, Prague-west, Czech Republic.

Specimens of the presently described species are provided with red, printed labels with the text as follows: «HOLOTYPE [or PARATYPE, respectively] name of taxon sp. nov. Jiří Háva det. 2019».

\section{Results}

Thaumaglossa Redtenbacher, 1867

Thaumaglossa hilleri species group

Thaumaglossa mentawaiana Háva, sp.n. Figs 1-2.

Type material. Holotype ( $\left.\sigma^{7}\right)$ : «IND: Mentawai Isl., S Siberut I., 50-100 m, Salappa vill., II.2007, S. Jákl lgt.», (JHAC). Paratype (P): same data as holotype, (JHAC).

Description. Male: Body (TL: $3.4 \mathrm{~mm}$, EW: $2.7 \mathrm{~mm}$ ), strongly convex, ovate, widest at humeri, black on dorsal surface; antennae brown, legs brown; body covered with black and yellow setation. Antennae with 11 antennomeres with characteristic morphology: the last (11th) antennomere leafshaped, densely covered with light-brown, erect setation (Fig. 1). The remaining segments of antenna narrow and triangular. Antenna occupies the whole cavity of antennal fossa. Antennal fossa completely open along the whole length of lateral margin of the pronotum (hypomeron), occupying all of hypomeron, deeply excavated, floor of fossa microscopically punctate. Pronotum black, densely punctate, covered by short, yellow and black setation. Elytra black, coarsely punctate on humeri and on first half, other parts densely punctate, covered with black, short setation. Epipleuron black with yellow setation. Scutellum triangular, shiny, visible, without setation. Prosternum intensely punctate on disc, without impunctate median line. Mesosternal disc with large punctation. Abdominal visible ventrites black with golden-yellow setation. Pygidium black, with black setation. Male genitalia as in Fig. 2 .

Female: externally similar to male, but terminal antennomere is very small. Body (TL $3.5 \mathrm{~mm}$ EW $2.8 \mathrm{~mm}$ ).

Differential diagnosis. The new species belongs to the $T$. hilleri species group, subgroup A, and is similar to species with black pygidium covered by black setae, abdomen black, but it differs from known species by the structure of anten- 
nae (terminal antennomere leaf-shaped, triangular) and male genitalia.

Etymology. Toponymic, named according to Mentawai Islands.

\section{Thaumaglossa sausai Háva, sp.n.}

Figs 3-4.

Type material. Holotype $\left(0^{7}\right)$ : «Laos south, Attapu prov, Bolaven Plateau, 18-30.iv.1991, $15 \mathrm{~km} \mathrm{SE}$ of Ban, Houaykong Nong Lom» / «(lake) env., alt. 800 m, 1502' N, 106 $35^{\prime}$ E, E. Jendek \& O. Šauša lgt.", (JHAC). Paratypes (3우): same data as holotype (JHAC); $\left(10^{7}\right)$ : «NW Thailand, Mae Hong Son distr, Soppong, $19^{\circ} 27^{\prime}$ N, 98 $20^{\prime}$ E, 1500 m, 7-12.5.1996, J. Horák lgt.”, (JHAC); (): «Thailand, Chuphon prov., Pha To env., 1-12.iii.1996, P. Prùdek lgt», (JHAC); (P): «Thailand, around accom. Area, outside, Khao Sok N.P., 9-11.4.2001, A. Kudrna lgt.», (JHAC).

Description. Male: Body (TL: $2.4 \mathrm{~mm}$, EW: $1.8 \mathrm{~mm}$ ), strongly convex, ovate, widest at humeri, black on dorsal surface; antennae brown, legs brown; body covered with black and yellow setation. Antennae with 11 antennomeres with characteristic morphology: the last (11th) antennomere leafshaped, covered densely with ligth-brown, erect setation (Fig. 3 ). The remaining segments of antenna narrow and oval. Antenna occupies the whole cavity of antennal fossa. Antennal fossa completely open along the whole length of lateral margin of the pronotum (hypomeron), occupying all of hypomeron, deeply excavated, floor of fossa microscopically punctate. Pronotum black, densely punctate, covered by long, yellow setation. Elytra black to very dark brown, coarsely punctate on humeri and on first half, other parts densely punctate, covered with black, short setation, only near epipleuron with yellow setation. Epipleuron black with yellow setation. Scutellum triangular, shiny, visible, without setation. Prosternum intensely punctate on disc, without impunctate median line.
Mesosternal disc with large punctation. Abdominal visible ventrites black with golden-yellow setation. Pygidium black, with yellow setation. Male genitalia as in Fig. 4.

Female: externally similar to male, but terminal antennomere is very small. Abdominal visible ventrites and pygidium very dark brown.

Variability. Male: Body (TL: $2.9 \mathrm{~mm}$, EW: $2.1 \mathrm{~mm}$ ). Female: Body (TL: 2.7-3.3 mm, EW: 1.9-2.8 mm).

Differential diagnosis. The new species belongs to the $T$. hilleri species group, subgroup $\mathrm{B}$, and is externally very similar to T. jendeki Háva, 2003 but differs from it by the following characters: 1 . Epipleuron and elytra near epipleuron covered by yellow setation (jendeki- with entirely black setation); 2. Parameres of aedeagus, long and narrow (jendeki parameres short and broad); from other species it differs by the structure of antennae and male genitalia.

Etymology. Patronymic, dedicated to Ondrej Šauša (Bratislava, Slovakia), my friend and collector of the new species.

\section{Faunistics}

\section{Thaumaglossa pacholatkoi Háva, 2015}

Material. «W Java, Djampang Tengah, 1800 ft, 48.VI.1939, J.M.A. v. Groenendael», +, J. Háva det. (JHAC).

Distribution. A species known from Malaysia, new to Indonesia: Java I.

Thaumaglossa panda Herrmann et Háva, 2015

Material. China, E Hubei, Dabie Shan, Wujiashan forest park, 31.1N 115.8E, 7-10.V.2004, J. Turna lgt., 3우, J. Háva det., (JHAC).

Distribution. Species known from China: Sichuan prov., new for Hubei prov.
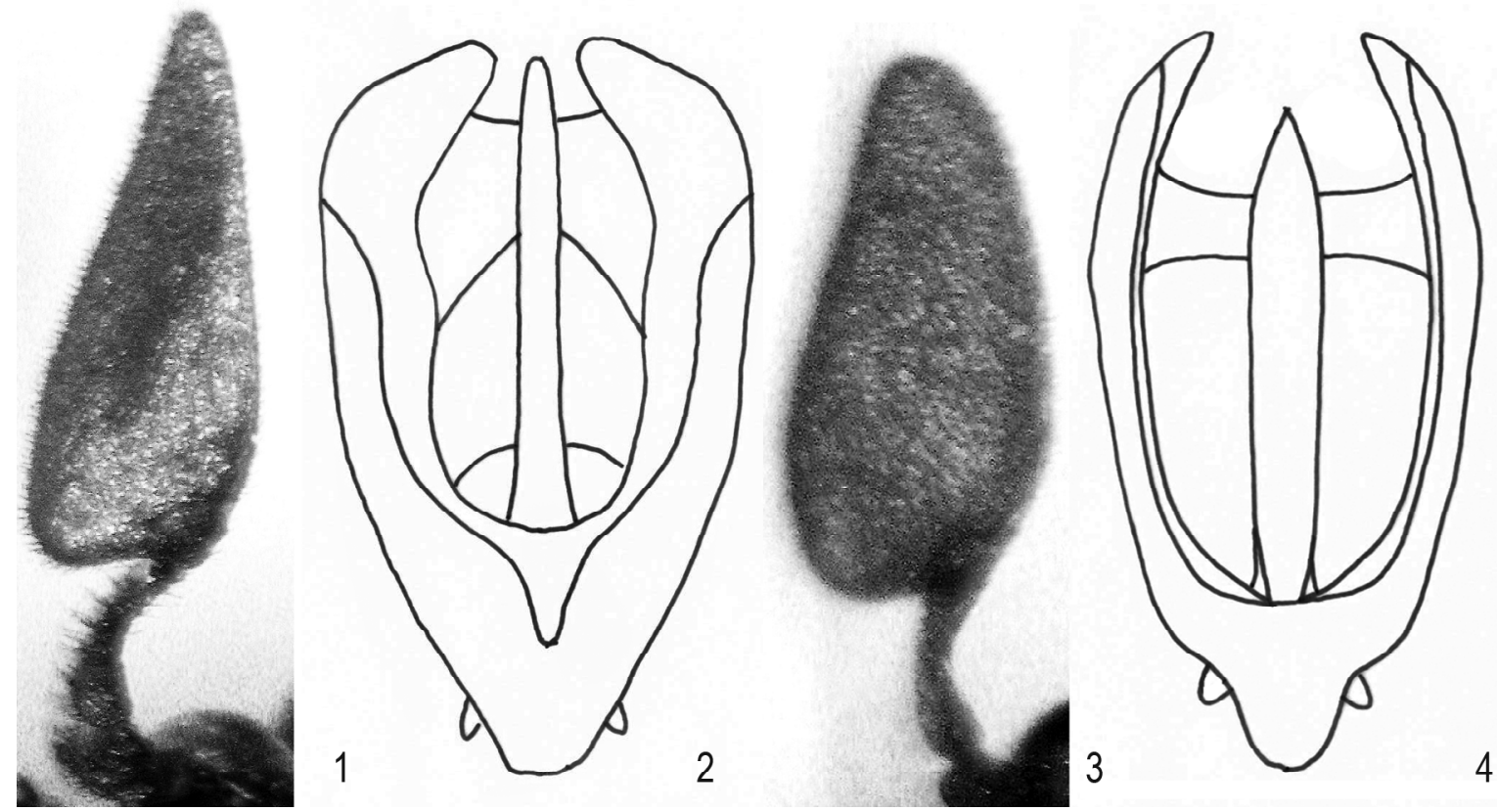

Figs 1-4. Thaumaglossa spp. 1-2 - T. mentawaiana sp.n. 1 - antenna of male, $2-$ male genitalia. $3-4-$ T. sausai sp.n.: 3 - antenna of male, 4 - male genitalia.

Рис. 1-4. Новые виды рода Thaumaglossa: $1-2-$ T. mentawaiana sp.n.: 1 - усик самца; 2 - гениталии самца. 3-4 T. sausai sp.n.: 3 - усик самца; 4 - гениталии самца. 


\section{Known species of $T$. hilleri species group from Oriental Region}

Subgroup $\boldsymbol{A}$ - pygidium black with black setae; abdominal ventrites black; pronotum covered by black setation:

T. hilleri Reitter, 1881: China; India; Japan; Laos; Nepal; Philippines; Taiwan;

T. panda Herrmann et Háva, 2015: China: Sichuan, Hubei;

T. chujoi Ohbayashi, 1982: Indonesia: Maluku: Ambon I.; Japan, Taiwan;

T. mentawaiana sp.n.: Indonesia: Mentawai Is.;

T. parahilleri Kadej et Háva, 2013: Laos.

Subgroup B - pygidium black with yellow setae; abdominal ventrites black; pronotum covered by yellow setation:

T.jendeki Háva, 2003: Laos;

T. sausai sp.n.: Laos, Thailand;

T. wittmeri Háva, 2006: Nepal; India: Sikkim, Uttar Pradesh.

Subgroup C - pygidium brown with yellow setae; abdominal ventrites brown; pronotum covered by yellow setation: Java

T. pacholatkoi Háva, 2015: Malaysia, Indonesia: W

T. pseudohilleri Háva, 2006: India: Maharashtra.

\section{Acknowledgements}

I am indebted very much to all collectors for providing me with the interesting material and to Miloslav Rakovič (Czech Republic) for revision of the English manuscript.

\section{References}

Háva J. 2008. Revision of the Thaumaglossa tonkinea species group (Coleoptera: Dermestidae: Megatominae) from Oriental Region // Calodema Supplementary Paper 86. P.1-6.

Háva J. 2010. A new species of Thaumaglossa (Coleoptera: Dermestidae: Megatomini) from Timor Island // Latvijas Entomologs. Vol.48. P.50-51.
Háva J. 2012. Thaumaglossa baobab sp. nov., new species from Madagascar (Coleoptera: Dermestidae: Megatomini) // Calodema. Vol.199. P.1-4.

Háva J. 2015a. World Catalogue of Insects. Vol.13. Dermestidae (Coleoptera). Leiden/Boston: Brill, XXVI +419 p.

Háva J. 2015b. Contribution to the knowledge of genus Thaumaglossa from Central America (Coleoptera: Dermestidae: Megatominae) // Arquivos Entomolóxicos. Vol.14. P.33-36.

Háva J. 2015c. A new Thaumaglossa species from Nepal (Dermestidae: Megatominae) // Biodiversity and Natural Heritage in the Himalaya. Vol.5. P.443-444.

Háva J. 2015d. A contribution to knowledge of the genus Thaumaglossa species from Malaysia with description of two new species (Coleoptera: Dermestidae: Megatominae) // Folia Heyrovskyana. Ser.A. Vol.23. No.1. P.14-17.

Háva J. 2017. Thaumaglossa navratili sp. nov. from French Guiana (Coleoptera: Dermestidae: Megatominae) // Arquivos Entomolóxicos. Vol.18. P.127-130.

Háva J. 2020. Dermestidae World (Coleoptera) // World Wide Web electronic publication (open in 2004): http:// www.dermestidae.wz.cz (version 2018, update January $2020)$.

Háva J., Jakl S. 2018. A new species of Thaumaglossa Redtenbacher, 1867 from Central Sulawesi (Coleoptera: Dermestidae: Megatominae) // Folia Heyrovskyana. Ser.A. Vol.26. No.2. P.4-7.

Háva J., Kadej M., Casari S.A. 2006: Revision of the genera Thaumaglossa Redtenbacher, 1867 and Pseudothaumaglossa Pic, 1918 (Coleoptera: Dermestidae: Megatomini) from Neotropical region // Polskie Pismo Entomologiczne. Vol.75. P.391-399.

Herrmann A., Háva J. 2013. Description of a new species of Thaumaglossa Redtenbacher, 1867 (Coleoptera: Dermestidae) from the Republic of Equatorial Guinea (West Africa) // Arquivos Entomoloxicos. Vol.8. P.231-233.

Herrmann A., Háva J. 2015. A new species of the genus Thaumaglossa Redtenbacher, 1867 (Coleoptera: Dermestidae) from China // Folia Heyrovskyana. Ser.A. Vol.22. No.2. P.17-20.

Kadej M., Háva J. 2013. A new Thaumaglossa Redtenbacher, 1867 species from Laos (Coleoptera: Dermestidae: Megatomini), with a key to the Laosan species // Annals of the Entomological Society of America. Vol.106. P.555561 .

Kadej M., Háva J. 2015. A contribution to the knowledge of Dermestidae (Insecta, Coleoptera) of Laos with description of four new species // Annals of the Entomological Society of America. Vol.108. No.5. P.912-921. 